\title{
Alterations in ocular pathog'en susceptibility to gentamicin and tobramycin
}

\author{
Alterações na sensibilidade dos patógenos oculares à gentamicina e à tobramicina
}

Cecília Tobias de Agiuiar Moeller ${ }^{(1)}$

Bruno Castelo Branco ${ }^{(2)}$

Maria Cecília Zorat Yu ${ }^{(3)}$

Michel Eid Farah ${ }^{(4)}$

Ana Luisa Höfling'-Lima ${ }^{(5)}$
Os autores declaram não possuírem interesses financeiros no desenvolvimento deste estudo.

Graduanda do quinto ano médico da Universidade Federal de São Paulo da UNIFESP/Escola Paulista de Medicina (EPM).

(2) Residente de terceiro ano do Departamento de Oftalmologia da UNIFESP-EPM.

(3) Biomédica do Laboratório de Microbiologia Ocular do Departamento de Oftalmologia da UNIFESP-EPM - Hospital São Paulo.

(4) Professor Livre-Docente de Oftalmologia pelo Departamento de Oftalmologia da UNIFESP-EPM Hospital São Paulo.

(5) Prof. Adjunto-Doutor e chefe do Laboratório de Microbiologia Ocular do Departamento de Oftalmologia da UNIFESP-EPM - Hospital São Paulo. Os dados deste estudo foram obtidos no Laboratório de Microbiologia Ocular do Departamento de Oftalmologia da UNIFESP-EPM - Hospital São Paulo - SP - Brasil.

Endereço para correspondência: Cecília Tobias de Aguiar Moeller. Rua Prof. Sebastião Hermeto Júnior, 81. São Paulo (SP). CEP 04623-160. e mail: cicamoeller@hotmail.com

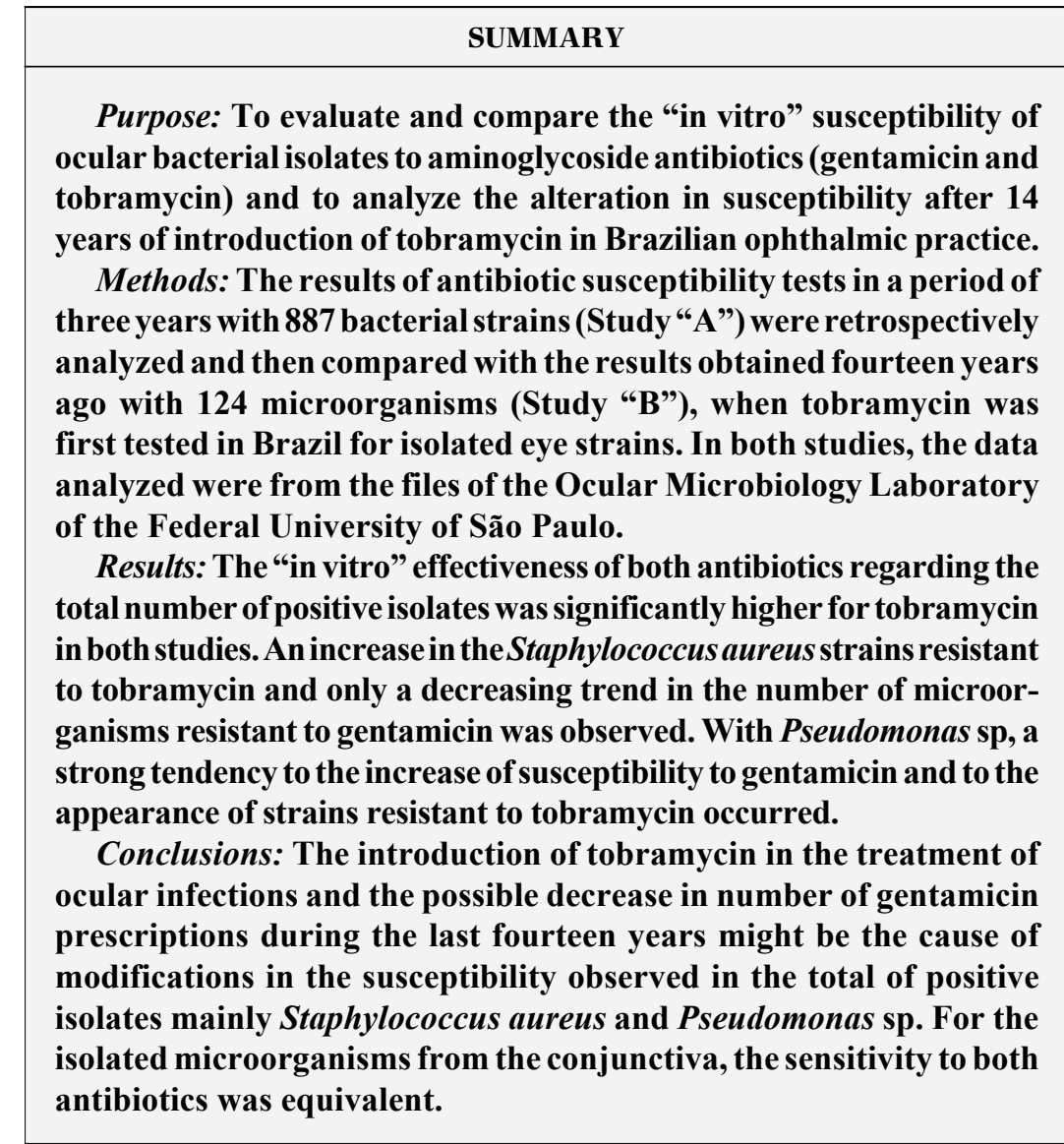

Keywords: Ocular Infections; Antibiotic susceptibility; Gentamicin and Tobramycin.

\section{INTRODUCTION}

The most frequent infections of the cornea and conjunctiva, which are submitted to a laboratory evaluation in our environment, are due to bacteria, and an initial treatment with broad spectrum antibiotics is usually recommended after the clinical diagnosis and after scraping the site of infection ${ }^{1,2}$. In most situations, mainly for corneal infections, the initial treatment starts before the confirmation of culture results. Conjunctival cultures are not always necessary and recommended.

Susceptibility tests to microorganisms isolated from ocular infections are recommended since the results are useful not only in specific cases but also as epidemiological data ${ }^{2,3}$. 
Gentamicin and tobramycin, of well-known use in ophthalmology, belong to the aminoglycoside group together with streptomycin and neomycin ${ }^{4-7}$. Their mechanism of action is by means of binding to the bacterial ribosome, inhibiting protein synthesis. In general they are bacteriostatic, but in higher doses, they may have bactericidal property ${ }^{7}$. The spectrum of the aminoglycoside action includes both Gram negative and Gram positive microorganisms 2,4,5,6,8.

Gentamicin and tobramycin, as eye drops, are stable solutions. The commercially available concentration is $3 \mathrm{mg} /$ $\mathrm{ml}$ which is the ideal concentration recommended for the treatment of eyelid and conjunctiva infections 5,8 .

The results of the "in vitro" antimicrobial susceptibility tests by the time of tobramycin introduction for the treatment of eye infections, showed a greater efficacy of tobramycin regarding all microorganisms isolated from ocular infections, specially Pseudomonas sp and Staphylococcus aureus, when compared with the results of gentamicin susceptibility $5,6,9,10$.

The purpose of this study is to evaluate and compare the "in vitro" susceptibility to gentamicin and tobramycin to ocular microorganisms of the conjunctiva, cornea and intraocular fluids, isolated by the Ocular Microbiology Laboratory of the Federal University of São Paulo (UNIFESP-EPM) and also to evaluate alterations in the susceptibility occurred by the analysis of a previous study carried out fourteen years ago in the same institution.

\section{MATERIAL AND METHODS}

The Ocular Microbiology Laboratory of UNIFESP - EPM receives material for cultures and microbiological evaluation from patients treated at the São Paulo Hospital and also in the community.

The samples for microbiological evaluation are collected directly from the infected area in all cases of lid, conjunctival and corneal infections. In the case of intraocular infection, paracentesis is performed in the anterior and vitreous chamber.

Cotton swabs soaked in Brain-Heart-Infusion (BHI) solution are used for collection of samples for cultures from the conjunctiva. Corneal samples were obtained using a Kimura platinum spatula and those of the aqueous and vitreous humor through direct puncture of the anterior chamber. The aqueous samples were also obtained by filtration of diluted Balanced Salt Solution (BSS) material collected during vitrectomy performed for infected cases.

All samples were cultured in chocolate agar, blood agar and Sabouraud dextrose agar ${ }^{3,11}$. From each sample, smears stained by the Gram and Giemsa methods were obtained for bacterioscopy and cytology respectively.

Cultures were considered positive when presenting a significant growth of at least two seeded samples in one or more plates.

The isolated microorganisms were submitted to antibiotic susceptibility tests using the disk diffusion method ${ }^{2,6}$ with an observed concentration in the disc of $10 \mu \mathrm{g}$ for both antibiotics ${ }^{2}$. The reading was performed by measuring the diameter of the inhibiting zone around the disk ${ }^{2}$, in agreement with the National Committee for Clinical Laboratory Standards (NCCLS) criteria for both antibiotics: resistant $(\leq 12 \mathrm{~mm})$; intermediate (13-14 $\mathrm{mm})$ and susceptible $(\geq 15 \mathrm{~mm})^{1-3}$.

The results of laboratory tests of cases referred to the Ocular Microbiology Laboratory of UNIFESP - EPM were retrospectively analyzed during the period from June 1995 to May 1998 (Study "A") and then compared with the results obtained from May 1983 to January 1985 (Study "B").

Of the 2,293 cases of Study "A", 1,840 cultures were carried out, with positive results in 827 cases. Isolation of only one organism was observed in 792 cases while 95 presented growth of more than one microorganism. Therefore, this study consisted of 887 bacteria that were submitted to antibiotic susceptibility tests.

In Study "B", of 112 cultures, 124 microorganisms were isolated. Only microorganisms with a more significant positive growth were used for comparison of results regarding the alteration in susceptibility between the two analyses.

In order to simplify analysis of the results of these studies, strains were grouped as follows: Staphylococcus aureus (S. aureus); coagulase-negative Staphylococcus (CNS); other Gram positive cocci (CGP) such as Streptococcus pneumoniae, non-hemolytic Streptococcus, Streptococcus viridians and Streptococcus pyogenes; Moraxella sp (Morax); Pseudomonas sp (Pseudo); other Gram negative microorganisms (Gram Neg) such as Proteus mirabilis, Proteus vulgaris, Proteus sp, Serratia sp, Citrobacter sp, Enterobacter sp, Klebsiella sp, Hafnia alvei, Listeria sp, Neisseria sp, Providencia sp, E. coli and Morganella morganii; Haemophilus sp (Haem) and Gram positive microorganisms (Gram Pos) such as Bacillus sp and C.xerosis.

In the two studies, analysis and comparison of ocular pathogen susceptibility to both antibiotics were performed in relation to the total isolated microorganisms and to each group of microorganisms apart from the site of collection. Then, in Study "A", susceptibility to each group of microorganisms regarding the site of the collection was also analyzed and compared. In Study "B", due to the small sample of each site of collection, no analysis or comparisons of the susceptibility to both antibiotics were performed.

In both studies, statistical analysis using the chi-square test was used for one sample, assuming that the theoretical distribution of the number of sensitive cases was equitably distributed among the different sites of collection ${ }^{12,13}$. In order to verify the differences between the proportion of microorganisms susceptible to gentamicin and tobramycin, a test for two proportions, whose populations were not independent, was used as proposed by Mc Nemar. The statistics calculated was defined as $\mathrm{Uo}^{2}{ }^{(12)}$. Level of significance was $0.05(5 \%)$. Significant $\mathrm{Uo}^{2}$ statistics is marked by an asterisk $(*)^{12}(\mathrm{p} \leq$ $0.05)$. N.S. means a nonsignificant statistics $(p \geq 0.05)^{13}$. 
When comparing the present results of susceptibility with those obtained fourteen years ago, the test for two independent proportions was used when the sample was significant and the statistics were then defined as $z^{14}$. When the sample was smaller, as in the case of Pseudomonas sp found in Study "B", the Fisher's test was used ${ }^{13}$. For both tests, the level of significance was 0.05 (5\%). The above mentioned parameters of significance were used ${ }^{12,13}$.

\section{RESULTS}

Of the 887 bacteria isolated in Study “A”, 484 were from the conjunctiva, 324 from the cornea, 36 from aqueous and/or vitreous humor and 43 from varied areas such as limbus and contact lenses. Of the 124 positive isolates found in Study "B", 44 were from the conjunctiva, 22 from the cornea, 1 from aqueous and/or vitreous humor, 40 from lids and 18 from the lacrimal sac.

Regarding the frequency of microorganisms in Study "A", 365 CNS were identified which is comparable to $41.2 \%$ of the total, while $S$. aureus was the second most frequent microorganism with 222 positive isolates (25.0\%). Concerning Gram negative microorganisms, Pseudomonas sp was the most frequently isolated with 5.9\% (Table 1). Data from Study "B" emphasize the high frequency of S. aureus (83.1\%) while the

\begin{tabular}{|c|c|c|c|c|c|c|}
\hline \multirow{3}{*}{ Bacteria } & \multirow{3}{*}{$\mathbf{N}$} & \multicolumn{4}{|c|}{ Antibiotics } & \multirow{3}{*}{$\begin{array}{c}\text { Calculated Statistics } \\
\qquad \mathrm{U}^{2} \\
\mathrm{X} \mathrm{crit}^{2}>3,84\end{array}$} \\
\hline & & \multicolumn{2}{|c|}{$\begin{array}{l}\text { Gentamicin } \\
\text { Susceptible }\end{array}$} & \multicolumn{2}{|c|}{$\begin{array}{l}\text { Tobramycin } \\
\text { Susceptible }\end{array}$} & \\
\hline & & $\mathbf{N}$ & $\%$ & $\mathbf{N}$ & $\%$ & \\
\hline CNS & 365 & 305 & 83.6 & 303 & 83.0 & 0,096 N.S. \\
\hline S. aureus & 222 & 169 & 76.1 & 187 & 84.2 & $7,349\left(^{*}\right)$ \\
\hline CGP & 117 & 48 & 41.0 & 54 & 46.2 & 1,631 N.S. \\
\hline Gram Neg & 63 & 59 & 93.7 & 57 & 90.5 & 0 N.S. \\
\hline Pseudo & 53 & 44 & 83.0 & 46 & 86.8 & 0,998 N.S. \\
\hline Morax & 40 & 38 & 95.0 & 37 & 92.5 & 1 N.S. \\
\hline Haem & 18 & 15 & 83.3 & 16 & 88.9 & 1 N.S. \\
\hline Gram Pos & 9 & 9 & 100 & 9 & 100 & T.E. \\
\hline TOTAL & 887 & 687 & 77.5 & 709 & 79.9 & $4,249\left(^{*}\right)$ \\
\hline \multicolumn{7}{|c|}{$\begin{array}{l}\left.\text { Uo }{ }^{2} \text { : Statistical Test; T.E: Test exemption; N.S.: Not significant; ( }{ }^{\star}\right) \text { : Significant } \\
\text { CNS - coagulase-negative Staphylococcus; S. aureus - Staphylococcus aureus; CGP - other Gram Positive Cocci (Streptococcus pneumoniae, non-hemolytic } \\
\text { Streptococcus, Streptococcus viridans and Streptococcus pyogenes); Gram Neg - Gram negative microorganisms (Proteus mirabilis, Proteus vulgaris, Proteus sp, } \\
\text { Serratia sp, Citrobacter sp, Enterobacter sp, Klebsiella sp, Hafnia alvei, Listeria sp, Neisseria sp, Providencia sp, E. coli, Pseudomonas aeruginosa, Pseudomonas } \\
\text { fluorescens and Morganella morganil); Pseudo - Pseudomonas sp; Morax-Moraxella sp; Haem - Haemophilus sp; Gram Pos - Gram positive microorganisms (Bacillus } \\
\text { sp and C. xerosis). }\end{array}$} \\
\hline
\end{tabular}

\begin{tabular}{|c|c|c|c|c|c|c|}
\hline \multirow{3}{*}{ Bacteria } & \multirow{3}{*}{$\mathbf{N}$} & \multicolumn{4}{|c|}{ Antibiotics } & \multirow{3}{*}{$\begin{array}{c}\text { Calculated Statistics } \\
\qquad \mathrm{U}^{2} \\
\mathrm{X} \mathrm{crit}^{2}>3,84\end{array}$} \\
\hline & & \multicolumn{2}{|c|}{$\begin{array}{l}\text { Gentamicin } \\
\text { Susceptible }\end{array}$} & \multicolumn{2}{|c|}{$\begin{array}{l}\text { Tobramycin } \\
\text { Susceptible }\end{array}$} & \\
\hline & & $\mathbf{N}$ & $\%$ & $\mathbf{N}$ & $\%$ & \\
\hline S. aureus & 103 & 77 & 74.8 & 95 & 92.2 & $9.523\left(^{*}\right)$ \\
\hline Pseudo & 7 & 4 & 57.1 & 7 & 100 & 3.054 N.S. \\
\hline Gram Neg & 7 & 5 & 71.4 & 6 & 85.7 & 0.996 N.S. \\
\hline CNS & 2 & 2 & 100 & 2 & 100 & T.E. \\
\hline Morax & 2 & 2 & 100 & 1 & 50.0 & 1 N.S. \\
\hline CGP & 1 & 1 & 100 & 1 & 100 & T.E. \\
\hline Haem & 1 & 0 & 0 & 1 & 100 & 0 N.S. \\
\hline Gram Pos & 1 & 1 & 100 & 1 & 100 & T.E. \\
\hline TOTAL & 124 & 92 & 74.2 & 114 & 91.9 & $12.114\left(^{*}\right)$ \\
\hline
\end{tabular}


most frequent microorganism was Pseudomonas sp (5.6\%) with only 7 strains (Table 2). Since this study is related to antibiotic susceptibility tests, there is an explanation for the difference in frequency of CNS between the two studies. When Study "B" was performed, the CNS isolated at the Laboratory was not submitted to susceptibility tests.

The analysis of the susceptibility results of the total microorganisms isolated in both studies shows a difference between the microbial susceptibility of both antibiotics tobramycin being a more efficacious antibiotic mainly against S. aureus (Table 1, 2 and 5).

In Study "A", with a large number of isolates from each site of infection (conjunctiva, cornea and intraocular fluids), we could compare the antibiotic susceptibility results of each group of microorganisms at all sites of infection. With this evaluation, we could show that tobramycin was more effective "in vitro" than gentamicin against $S$. aureus isolated from corneal infections (Table 3). The difference observed regarding Staphylococcus aureus interferes with the analysis of susceptibility of the total of these microorganisms, when we analyzed all sites of collection (Table 1).

The results of Pseudomonas sp susceptibility to tobramycin and gentamicin were respectively, $86.8 \%$ and $83.0 \%$ in Study "A" and 100\% and 57.1\% in Study "B", without a statistically significant difference of effectiveness between both antibiotics. (Tables 1, 2).

The comparison of the present susceptibility results with those obtained 14 years ago showed an inferior susceptibility to tobramycin in relation to the total analyzed bacteria (Table 5). An increase in the Staphylococcus aureus strains resistant to tobramycin was observed and only a trend towards a decrease in the number of strains of this microorganism resistant to gentamicin (Tables 4, 5).
Regarding Pseudomonas sp, there is a strong tendency to increase in the susceptibility to gentamicin and the appearance of strains resistant to tobramycin (Tables 4, 5).

CNS isolates in Study "B" were in small number, not allowing comparison of the results between the studies.

\section{CONCLUSIONS}

"In vitro" susceptibilities of isolated ocular microorganisms not always translate the reality of "in vivo" action of some specific drugs, but they are strong epidemiological indicatives ${ }^{2,15}$.

Similar to other previous evaluations, a great number of cultures carried out in this study did not present growth of microorganisms. There are several explanations for this fact like the presence of viral infections, use of topical antibiotics before cultures were performed, insufficient material, the presence of microorganisms that do not grow in regular media such as anaerobic bacteria and Mycobacteria ${ }^{11,16}$.

Gram positive cocci are the most frequent bacteria isolated from conjuntival, corneal and intraocular infection in several series and also the most frequent isolated from conjunctival normal flora $1,2,11,10,17$

The microorganisms isolated from the eyes are more susceptible to tobramycin than to gentamicin but the difference between the susceptibilities of these two antibiotics is smaller in the recent study (Tables 1,2 ).

In order to look for the greatest susceptibility difference in the data obtained from Study "A", we analyzed the several sites of collection and the different groups of microorganisms, finding that the Staphylococcus aureus strains isolated in cases of corneal ulcer were significantly more susceptible to tobramycin than to gentamicin (Table 3). This datum has been

\begin{tabular}{|c|c|c|c|c|c|c|}
\hline \multicolumn{7}{|c|}{$\begin{array}{l}\text { Table 3. Antibiotic susceptibility of microorganismis isolated from the cornea to gentamicin and } \\
\text { tobramycyn (Study "A") } 1999 \text { - São Paulo - Brazil }\end{array}$} \\
\hline \multirow{3}{*}{ Bacteria } & \multirow{3}{*}{$\mathbf{N}$} & \multicolumn{4}{|c|}{ Antibiotics } & \multirow{3}{*}{$\begin{array}{c}\text { Calculated Statistics } \\
\qquad \mathrm{U}^{2} \\
\mathrm{X} \mathrm{crit}^{2}>3,84\end{array}$} \\
\hline & & \multicolumn{2}{|c|}{$\begin{array}{l}\text { Gentamicin } \\
\text { Susceptible }\end{array}$} & \multicolumn{2}{|c|}{$\begin{array}{l}\text { Tobramycin } \\
\text { Susceptible }\end{array}$} & \\
\hline & & $\mathbf{N}$ & $\%$ & $\mathbf{N}$ & $\%$ & \\
\hline CNS & 76 & 62 & 81.6 & 58 & 76.3 & 1.142 N.S. \\
\hline S. aureus & 68 & 49 & 72.1 & 60 & 88.2 & $7.121\left(^{*}\right)$ \\
\hline CGP & 74 & 28 & 37.8 & 34 & 45.9 & 2.571 N.S. \\
\hline Gram Neg & 25 & 24 & 96.0 & 24 & 96.0 & T.E. \\
\hline Pseudo & 46 & 39 & 84.8 & 40 & 87.0 & 0.335 N.S. \\
\hline Morax & 32 & 30 & 93.8 & 29 & 90.6 & 0.998 N.S. \\
\hline Haem & 2 & 2 & 100 & 2 & 100 & T.E. \\
\hline Gram Pos & 1 & 1 & 100 & 1 & 100 & T.E. \\
\hline TOTAL & 324 & 235 & 72.5 & 248 & 76.5 & 0.184 N.S. \\
\hline \multicolumn{7}{|c|}{$\begin{array}{l}\text { U }{ }^{2} \text { : Statistical Test; T.E: Test exemption; N.S.: Not significant; }\left({ }^{*}\right) \text { : Significant } \\
\text { CNS - coagulase-negative Staphylococcus; S. aureus - Staphylococcus aureus; CGP - other Gram Positive Cocci (Streptococcus pneumoniae, non- } \\
\text { hemolytic Streptococcus, Streptococcus viridans and Streptococcus pyogenes); Gram Neg - Gram negative microorganisms (Proteus mirabilis, } \\
\text { Proteus vulgaris, Proteus sp, Serratia sp, Citrobacter sp, Enterobacter sp, Klebsiella sp, E. coli, Pseudomonas aeruginosa, Pseudomonas fluorescens } \\
\text { and Morganella morganii); Pseudo- Pseudomonas sp; Morax - Moraxella sp; Haem - Haemophilus sp; Gram Pos - Gram positive microorganisms } \\
\text { (Bacillus sp and C. xerosis). }\end{array}$} \\
\hline
\end{tabular}




\begin{tabular}{|c|c|c|c|c|c|}
\hline \multirow{4}{*}{ Bacteria } & \multicolumn{4}{|c|}{ Antibiotics } & \multirow{4}{*}{$\begin{array}{c}\text { Calculated Statistics } \\
\qquad \mathrm{p} \leq 0.05\end{array}$} \\
\hline & \multirow{2}{*}{\multicolumn{2}{|c|}{ Study "A" }} & & & \\
\hline & & & \multicolumn{2}{|c|}{ Study "B" } & \\
\hline & $\mathbf{N}$ & $\%$ & $\mathbf{N}$ & $\%$ & \\
\hline CNS & 305 & 83.6 & 2 & 100 & n.c. \\
\hline S. aureus & 169 & 76.1 & 77 & 74.8 & 0.8026 N.S. \\
\hline CGP & 48 & 41.0 & 1 & 100 & n.c. \\
\hline Gram Neg & 59 & 93.7 & 5 & 71.4 & n.c. \\
\hline Pseudo & 44 & 83.0 & 4 & 57.1 & 0.1108 N.S. \\
\hline Morax & 38 & 95.0 & 2 & 100 & n.c. \\
\hline Haem & 15 & 83.3 & 0 & 0 & n.c. \\
\hline Gram Pos & 9 & 100 & 1 & 100 & n.c. \\
\hline TOTAL & 687 & 77.5 & 92 & 74.2 & 0.3954 N.S. \\
\hline \multicolumn{6}{|c|}{$\begin{array}{l}p=\text { Statistical Test; n.c. = Not calculated (sample not representative); N.S.= Not significant } \\
\text { CNS - coagulase-negative Staphylococcus; S. aureus - Staphylococcus aureus; CGP - other Gram Positive Cocci (Streptococcus pneumoniae, non- } \\
\text { hemolytic Streptococcus, Streptococcus viridans and Streptococcus pyogenes); Gram Neg - Gram negative microorganisms (Proteus mirabilis, } \\
\text { Proteus vulgaris, Proteus sp, Serratia sp, Citrobactersp, Enterobacter sp, Klebsiella sp, Hafnia alvei, Listeria sp, Neisseria sp, Providencia sp, E. coli, } \\
\text { Pseudomonas aeruginosa, Pseudomonas fluorescens and Morganella morganii); Pseudo Pseudomonas sp; Morax - Moraxella sp; Haem - Haemophilus } \\
\text { sp; Gram Pos - Gram positive microorganisms (Bacillus sp and C. xerosis). }\end{array}$} \\
\hline
\end{tabular}

observed constantly in the evaluations performed in the same laboratory when the susceptibility of isolated strains of the cornea is compared with that of isolated strains of the conjunctiva, the microorganisms isolated from the cornea being more resistant than the isolates from the conjunctiva.

Regarding the option for treatment of Pseudomonas $\mathrm{sp}$ infections, tobramycin prescription is still preferable to gentamicin since these bacteria present levels of susceptibility over $86 \%$, considering that the most important action spectrum of the aminoglycoside antibiotics is on Gram negative bacteria.

The comparison of the results of both studies, one performed at the time when tobramycin was first tested for topic use in Brazil (Study "B") and the other at present (Study “A"), has demonstrated that the susceptibility of ocular isolates to aminoglycoside antibiotics has changed in the last years (Tables $4,5)$ since increase in bacterial resistance to tobramycin has been noted. This alteration can be analyzed for $S$. aureus groups and, possibly, for Pseudomonas sp, the susceptibilities in Study "A" being $84.2 \%$ and $86.8 \%$, respectively, and in Study "B" $16,1792.2 \%$ and $100 \%$, respectively. The number of positive isolates of other microorganisms found in Study "B" was not significant, not allowing analysis and comparison in the present study. The difference in frequency of CNS submitted to antibiotic susceptibility tests observed in the two studies is due

\begin{tabular}{|c|c|c|c|c|c|}
\hline \multicolumn{6}{|c|}{$\begin{array}{l}\text { Table 5. Comparison of antibiotic susceptibility of different isolated groups of ocular microorganisms } \\
\text { to tobramycin - São Paulo - Brazil }\end{array}$} \\
\hline \multirow{4}{*}{ Bacteria } & \multicolumn{4}{|c|}{ Antibiotics } & \multirow{4}{*}{$\begin{array}{c}\text { Calculated Statistics } \\
\qquad \mathrm{p} \leq 0.05\end{array}$} \\
\hline & \multirow{2}{*}{\multicolumn{2}{|c|}{ Study "A" }} & \multicolumn{2}{|c|}{ Tobramycin } & \\
\hline & & & \multicolumn{2}{|c|}{ Study "B" } & \\
\hline & $\mathbf{N}$ & $\%$ & $\mathbf{N}$ & $\%$ & \\
\hline CNS & 303 & 83.0 & 2 & 100 & n.c. \\
\hline S. aureus & 187 & 84.2 & 95 & 92.2 & $0.0478\left(^{*}\right)$ \\
\hline CGP & 54 & 46.2 & 1 & 100 & n.c. \\
\hline Gram Neg & 57 & 90.5 & 6 & 85.7 & n.c. \\
\hline Pseudo & 46 & 86.8 & 7 & 100 & 0.3990 N.S. \\
\hline Morax & 37 & 92.5 & 1 & 50.0 & n.c. \\
\hline Haem & 16 & 88.9 & 1 & 100 & n.c. \\
\hline Gram Pos & 9 & 100 & 1 & 100 & n.c. \\
\hline TOTAL & 709 & 79.9 & 114 & 91.9 & $0.0012\left(^{*}\right)$ \\
\hline
\end{tabular}


to the orientation given by the time of Study "B" when the collections from the conjunctiva with positive CNS growth were not submitted to susceptibility tests for several antibiotics.

Regarding microorganism susceptibility to gentamicin, the alteration found during these years was a trend towards an increase in susceptibility not only in relation to total positive isolates but also for Pseudomonas sp and $S$. aureus groups.

Even after 14 years of using tobramycin in the treatment of ocular infections, the isolated ocular bacteria present a greater susceptibility to tobramycin as compared with the number of microorganisms susceptible to gentamicin.

In spite of infections of the conjunctiva being in general the most frequent ocular infections, corresponding to a great number of positive isolates, not all cases will be submitted to laboratory evaluation. We believe that several positive bacteria isolated from the conjunctiva correspond to the normal flora.

Although the results of "in vitro" microorganism susceptibility do not guarantee the equivalent clinical response, the microbial susceptibility to the two antibiotics presents levels that indicate the possibility of prescribing these drugs 1,3, mainly in relation to infectious caused by Gram negative organisms and, at a second level, for CNS and S. aureus.

This alteration of susceptibility of microorganisms demonstrated in these studies, mainly that of $S$. aureus to both antibiotics, is possibly due to the preference for prescribing tobramycin, most likely inducing the formation of resistant strains.

Other broad spectrum antibiotics are available for topical use, such as fluoroquinolones, that more recently were introduced for ophthalmic use and have shown to be a good choice for the treatment of several ocular infections.

The aminoglycosides gentamicin and tobramycin are stable antibiotics with good penetration in the cornea, when used in the correct doses, and do not present deposits when concomitantly used with contact lenses. They can be used for the treatment of corneal infections but the available concentration of antibiotics has to be adequately increased. This is also one of the great differences between aminoglycosides and fluoroquinolones, whose available commercial concentration for the treatment of conjunctival infection is adequate also for the treatment of corneal infection.

\section{RESUMO}

Objetivos: Avaliar e comparar a sensibilidade "in vitro" de bactérias isoladas do olho humano aos aminoglicosideos gentamicina e tobramicina, e analisar a mudança de sensibilidade ocorrida após quatorze anos de uso.

Métodos: Os resultados dos antibiogramas realizados no periodo de três anos com 887 bactérias (Estudo “ $A$ ”) foram comparados com os resultados obtidos há 14 anos com 124 microrganismos (Estudo “B”), quando tobramicina foi pela primeira vez testada no Brasil para cepas isoladas do olho. Resultados: A eficácia "in vitro" de ambos os antibióticos em relação ao total dos isolamentos positivos foi significantemente mais alta para a tobramicina em ambos os estudos.
A comparação dos resultados atuais de sensibilidade com aqueles obtidos há 14 anos demonstra uma menor sensibilidade à tobramicina com relação ao total de bactérias analisadas. Observou-se também um aumento de cepas de Staphylococcus aureus resistentes à tobramicina e apenas uma tendência à diminuição do número de cepas deste microrganismo resistentes à gentamicina. Com relação à Pseudomonas sp, existe uma forte tendência ao aumento de sensibilidade à gentamicina e o aparecimento de cepas resistentes à tobramicina.

Discussão: A introdução da tobramicina no tratamento de infecções oculares e uma provável diminuição do número de prescrições de gentamicina durante estes 14 anos podem ser a causa das modificações da sensibilidade observada do total de isolamentos positivos, principalmente de Staphylococcus aureus e Pseudomonas sp. Para os microrganismos isolados da conjuntiva, o espectro de ação dos dois antibióticos é equivalente.

Palavras-chave: Infecções oculares; Sensibilidade "in vitro"; Gentamicina; Tobramicina.

\section{REFERENCES}

1. Bower K, Kowalski R, Gordon Y. Fluoroquinolones in the treatment of bacterial keratitis. Am J Ophthalmol 1996;121:712-5.

2. Jensen H, Felix C. In vitro antibiotic susceptibilites of ocular isolates in North and South America. Cornea 1998;17:79-87.

3. Everett S, Kowalski R, Karenchak L, Landsittel D, Day R, Gordon, Y. An in vitro comparison of the susceptibilities of bacterial isolates from patient with conjuntivitis and blepharitiis to newer and established topical antibiotics. Cornea $1995 ; 14: 382-7$.

4. Purnell W, McPherson S. An evaluation of tobramycin in experimental corneal ulcers. Am J Ophthalmol 1974;78:318-20.

5. Laibson P, Michaud R, Smolin G, Okumoto M, Rosenthal A, Cagle G. A clinical comparison of tobramycin and gentamicin sulfate in the treatment of ocular infections. Am J Ophthalmol 1981;92:836-41.

6. Gwon A, Ofloxacin Study Group. Topical ofloxacin compared with gentamicin in the treatment of external ocular infection. Br J Ophthalmol 1992;76:714-8.

7. Santos PM, Nishi M, Guntzel I, Lima, ALH. 14 Princípios básicos do diagnóstico das Infecções oculares. In: Lima ALH, Calixto N, Melamed J, eds. Terapêutica Clínica Ocular. São Paulo: Editora Roca 1995;331-51.

8. Uwaydah M, Faris B. Penetration of tobramycin sulfate in the aqueous humor of rabbit. Arch Ophthalmol 1976;94:1173-84.

9. Lima ALH, Guidugli T, Almada AT, Belfort Jr R, Ferrari JA. Avaliação in vitro da atividade da tobramicina em infecções oculares. Rev Bras de Oftalmol 1985;44:141-5.

10. Lima ALH, Nishi M, Lottemberg CL, Guidugli T. Úlceras de córnea em serviço de referência. Arq Bras Oftalmol 1988;51:118-20.

11. Tomimatsu P, Almada A, Silva V, Belfort Jr. Úlceras bacterianas de córnea em São Paulo - Etiologia e sensibilidade a antibióticos in vitro. Arq Bras Oftalmol 1980;14:382-7.

12. Berquó ES, Souza JMP, Gotlieb SL. Bioestatística, $1^{\text {a }}$ ed. São Paulo: Editora: E.P.U (Ed. Pedagógica e Universidade Ltda.), 1981;17:292-7.

13. Siegel S. Estatística não paramétrica (para as ciências do comportamento), São Paulo: Editora Mc Graw-Hill Ltda. 1975;46-51.

14. Spiegel MR. Estatística, 2 ${ }^{\mathrm{a}}$ ed. São Paulo: Editora: Mc Graw-Hill Ltda, $1984 ; 233$

15. Smolin G, Okumoto M, Wilson M. The effect of tobramycin on Pseudomonas keratitis. Am J Ophthalmol 1973;76:555-60.

16. Lima ALH, Santos MAA, Belfort Jr R, Cabral JH, Mós EN, Farah ME. Microbiota anaeróbia e facultativa da conjuntiva normal de recém-nascido. Arq Bras Oftalmol 1993;56:138-45.

17. Wakisaka E, Ferreira MA, Rocha FJ, Freitas LL, Lima ALH. Cultura de material provindo de úlcera de córnea em laboratório de referência. Arq Bras Oftalmol 1990;53:193-200. 